\title{
ANALYSIS OF HYDRAULIC CONDUCTANCE COMPONENTS IN FIELD GROWN, MATURE SWEET CHERRY TREES
}

\author{
Ricardo Oyarzún ${ }^{1 *}$, Claudio Stöckle ${ }^{2}$, and Matthew Whiting ${ }^{3}$
}

\begin{abstract}
As a necessary step towards understanding soil water extraction and plant water relationships, the components of hydraulic conductance (K) of mature sweet cherry (Prunus avium L.) trees were evaluated in situ based on a Ohm's law analog method. In June 2004, K was determined for 10-yr-old 'Bing'/“Gisela ${ }^{\circledR}$ 5' trees, from simultaneous measurements of whole canopy gas exchange and leaf (sunlit and shaded) and stem water potentials ( $\Psi)$. Leaf water potential of sunlit leaves was lower than shaded leaves, reaching minimum values of $c a$. -2.3 MPa around 14:00 h (solar time). Average total hydraulic conductance was $60 \pm 6 \mathrm{mmol} \mathrm{s}^{-1} \mathrm{MPa}^{-1}$, presenting a slight decreasing trend as the season progressed. The analysis of tree $\mathrm{K}$ components showed that it was higher on the stem-leaf pathway $\left(150 \pm 50 \mathrm{mmol} \mathrm{s}^{-1} \mathrm{MPa}^{-1}\right)$, compared to the root-stem component $\left(100 \pm 20 \mathrm{mmol} \mathrm{s}^{-1} \mathrm{MPa}^{-1}\right)$, which is in agreement with literature reports for other fruit trees. A weak hysteresis pattern in the daily relationship between whole-canopy transpiration (weighted sunlit and shaded leaves) vs. $\Psi$ was observed, suggesting that water storage within the tree is not a significant component of sweet cherry water balance.
\end{abstract}

Key words: plant water relations, Prunus avium, transpiration, water potential, whole-canopy gas exchange.

\section{INTRODUCTION}

The hydraulic conductance $(\mathrm{K})$ of a plant characterizes its capability for water uptake and transport. Therefore, an understanding of $\mathrm{K}$ throughout the soil and plant system has been recognized as important for any study of the soil-plant-atmosphere continuum (Sperry et al., 2003). Several studies have described a direct relationship between whole plant hydraulic conductance and stomatal conductance, water use, and gas exchange (Hubbard et al., 2001; Schultz, 2003; Tyree, 2003; Cohen et al., 2007), therefore affecting plant transpiration and the plant potential for biomass accumulation. Also, rootstockinduced vigor control has been hypothetically related to lower K of certain rootstocks (Atkinson and Else, 2001; Basile et al., 2003; Olmstead et al., 2006; Cohen et al., 2007). While some studies state that roots exhibit the

${ }^{1}$ Universidad de La Serena, Departamento Ingeniería de Minas, Centro de Estudios Avanzados en Zonas Áridas (CEAZA), Benavente 980, La Serena, Chile. *Corresponding author (royarzun@userena.cl). ${ }^{2}$ Washington State University, Biological Systems Engineering Department, Pullman, Washington, 99163, USA.

${ }^{3}$ Irrigated Agriculture Research and Extension Center, WSU-Prosser, WA, 99350, USA.

Partial results of this work have been presented in the V International Cherry Symposium, Bursa, Turkey, 2005, and in the V Congreso Internacional de Ingeniería Agrícola (CIACH), Chillán, Chile, 2006. Received: 28 November 2008.

Accepted: 20 April 2009. lower conductances in fruit trees such as apple (Malus domestica Borkh.) and grapevine (Vitis labrusca L.) (Liu et al., 1978; Deme, 1984), others have shown that conductances of the pathway between roots and stem and stem-to-leaves are comparable in magnitude in fruit trees such as apricot (Prunus armeniaca L.) and orange (Citrus sinensis [L.] Osbeck) (Moreshet et al., 1990; Alarcón et al., 2003).

Traditionally, an analog of Ohm's law has been applied to water relations studies (Elfving et al., 1972), and it is still used (e.g. Alarcón et al., 2003; Tyree, 2003; Nicolás et al., 2005a; 2005b). This model proposes that the plant $\mathrm{K}$ is proportional to the steady state flux of water through the soil-plant-atmosphere continuum and inversely proportional to the driving force due to the difference in water potential between soil and leaves. This model assumes lack of significant capacitance (i.e., plant water storage), which is considered to be a reasonable assumption in herbaceous plants (Meinzer et al., 2001) as in fruit trees such as orange (Cohen et al., 1983), pecan (Carya illinoinensis [Wangenh.] K. Koch) (Steinberg et al., 1990) and apricot (Alarcón et al., 2003).

Most of the currently available data on plant hydraulic conductance on fruit trees have been obtained on young potted plants under controlled-laboratory conditions (Lovisolo et al., 2002; Basile et al., 2003), or in the field; however, only based on single leaf transpiration measurements (Marsal et al., 2000). Data on water 
relationships of mature fruit trees growing in commerciallike field conditions, in particular whole-tree hydraulic conductances integrating whole canopy transpiration and water potentials, are less common (Tognetti et al., 2004). Moreover, an important component of the study of plant-water relationships under field conditions is related to canopy-solar radiation interactions. Several studies have shown that in fruit trees, such as kiwi (Actinidia hemsleyana Dunn), apricot and citrus, the shaded portion of the canopy contributes in an important manner to whole canopy transpiration, despite the lower transpiration rates of shaded leaves in comparison to sunlit leaves (Xiloyannis et al., 2000). Therefore, to obtain a representative estimation of whole tree water relations, in particular transpiration and leaf water potential $\left(\Psi_{\mathrm{L}}\right)$, it is important to properly determine the fraction of sunlit and shaded leaves in the canopy. Previous efforts have included visual, subjective estimations of the sunlit/ shaded leaf ratio (e.g., Moreshet et al., 1990; Alarcón et al., 2003), but still there is a lack of a simple yet objective method to determine this parameter.

The main objective of this research was to obtain field estimates $\mathrm{K}$ for of mature sweet cherry (Prunus avium L.) on a whole-tree scale and to characterize the relative bearing of the different components of $\mathrm{K}$. This approach was similar to those followed by Moreshet et al. (1990) and Alarcón et al. (2003), but here a measurement of the sunlit leaf area fraction was performed.

\section{MATERIALS AND METHODS}

\section{Experimental conditions}

The study was carried out at the Roza experimental orchards of Washington State University-Irrigated Agriculture Research and Extension Center (WSUIAREC) near Prosser (46.2 ${ }^{\circ} \mathrm{N}, 119.7^{\circ} \mathrm{W}, 380$ m.a.s.1.) Washington, USA, during the summer of 2004.

Measurements were conducted on 9 yr-old 'Bing'/'Gisela ${ }^{\circledR} 5$ ' sweet cherry trees planted in NorthSouth rows $4.5 \mathrm{~m}$ apart, at a tree spacing of $2.5 \mathrm{~m}$, trained to a freestanding, standard multiple-leader, open-center architecture. Four trees with homogeneous size and development were chosen for this study. Leaf area of the trees $\left(\mathrm{L}_{\mathrm{t}}\right)$ was non-destructively estimated throughout the season as the sum of spur leaf area $\left(\mathrm{L}_{\mathrm{p}}\right)$ and shoot leaf area $\left(\mathrm{L}_{\mathrm{s}}\right)$ following the technique outlined by Whiting (2001). At full canopy, the rows formed a nearly-continuous hedge about $3.2 \mathrm{~m}$ tall and $2.8 \mathrm{~m}$ wide, with $\mathrm{L}_{\mathrm{t}}$ of $c a .38 \mathrm{~m}^{2}$.

The orchard soil (Warden coarse-silty, mixed, superactive, mesic xeric Haplocambids) is a silt loam, well-watered by under-tree micro-sprinkler irrigation at approximately weekly intervals.

\section{Tree transpiration}

Whole-tree transpiration was measured on selected days through the growing season, prior to harvest on 4 June, and after harvest on 24 and 26 June (DOY 156, 176, and 178 , respectively).

Previous to each measurement day, four trees were individually enclosed in the cuvettes, but only three of them were considered for $\mathrm{y}_{\mathrm{L}}$ measurements and derived analyses, while the fourth was kept as reference (Oyarzún, 2005).

Transpiration was determined from recorded water vapor differentials $\left(\mathrm{DH}_{2} \mathrm{O}\right.$, inlet vs. outlet) using an automated gas exchange system and a suite of four custom-designed inflatable Mylar cuvettes (Dupont, Wilmington, Delaware, USA) similar to those described in Whiting (2001). Cuvette dimensions were $c a .3 .0 \mathrm{~m}$ and $5.5 \mathrm{~m}$ of diameter and height. Ambient air was delivered to each chamber by an electric blower (model 5C197D of $1 \mathrm{HP}$ and 14 A, Dayton Electric, Niles, Illinois, USA) connected to the chambers by a galvanized sheet metal pipe of $1.5 \mathrm{~m}$ length and $0.3 \mathrm{~m}$ internal diameter (id). Outlet gases were drawn continuously from each cuvette via high density polyethylene tubing of $0.6 \mathrm{~cm}^{2}$ id under negative pressure from a vacuum pump (model 7920200, Cole Parmer, Vernon Hills, Illinois, USA). Switching among the cuvettes was achieved via solenoid valves controlled by a datalogger (CR10x, Campbell Scientific, Logan, Utah, USA). Inlet and outlet gases were analyzed by infra-red gas analysis (CIRAS DC, PP Systems, Haverhill, Massachusetts, USA) and the data were downloaded to a portable computer in the field.

The inlet water molar flow $\left(\mathrm{U}_{\mathrm{E}}, \mathrm{mmol} \mathrm{s} \mathrm{s}^{-1}\right)$ was estimated following Dragoni et al. (2005) as:

$$
\mathrm{U}_{\mathrm{E}}=\mathrm{F}(1 / 22.41)(273.15 / \mathrm{T})(\mathrm{P} / 1013)(1000 / 60)
$$

where $\mathrm{F}$ is the inlet volumetric flow at inlet $\left(\mathrm{L} \mathrm{min}^{-1}\right), \mathrm{T}$ is the inlet temperature $\left({ }^{\circ} \mathrm{K}\right)$, and $\mathrm{P}$ is the atmospheric pressure (mbar). The transpiration rate per tree $\left(\mathrm{E}, \mathrm{mmol} \mathrm{s}^{-1}\right)$ is then calculated as:

$$
\mathrm{E}=\left(\mathrm{U}_{\mathrm{E}} \Delta \mathrm{H}_{2} \mathrm{O}\right) /\left(\mathrm{P}-\left(\Delta \mathrm{H}_{2} \mathrm{O}+\mathrm{Xe}\right)\right)
$$

where $\mathrm{Xe}$ is the water vapor pressure at the inlet (mbar).

Inlet air velocity and temperature were measured intermittently during the experimental days using a TriSense Relative humidity-Wind velocity-Temperature probe (Cole Parmer, Vernon Hills, Illinois, USA). These measurements were performed on the chamber inlet pipe ca. $0.15 \mathrm{~m}$ from the chamber base by taking 11 readings, $1 \mathrm{~cm}$ depth incremental, at three positions on the perimeter of the aluminum pipe. 


\section{Leaf water potential}

Leaf water potential $\left(\Psi_{\mathrm{L}}\right)$ was measured using a portable pressure chamber (PPC) (PMS Instruments, Corvallis, Oregon, USA), at predawn $\left(\Psi_{\mathrm{PD}}, 04: 00 \mathrm{~h}\right)$ and then at 2-h intervals from 06:00 to 18:00 h (solar time), each experimental day when whole tree $\mathrm{E}$ was determined. Measurements of $\Psi_{\mathrm{PD}}$ were performed on three aluminumcovered, plastic-bagged leaves per tree, from three trees, following the methodology described by Ameglio et al (1999). Since the hourly sampling required the opening of the cuvettes, which induced brief disturbances in the air flow and microclimate conditions, the fourth tree was not used for $\Psi_{\mathrm{L}}$ measurements, but that chamber was kept undisturbed and used as a reference for E determinations.

Measurements included three replicates of uncovered sunlit leaves $\left(\Psi_{\mathrm{L}, \mathrm{L}}\right)$, uncovered shaded leaves $\left(\Psi_{\mathrm{L}, \mathrm{S}}\right)$, and leaves covered with aluminum foil and enclosed on plastic bags, i.e., xylem water potential $\left(\Psi_{\mathrm{x}}\right)$, per tree. The excised leaves were placed in a sealed plastic bag and then in a cooled ice chest and maintained at about $5{ }^{\circ} \mathrm{C}$ while the $\Psi_{\mathrm{L}}$ measurements were performed, which took ca. $40 \mathrm{~min}$ in average. The covered leaves were selected from shaded-inner parts of the canopy. These leaves were covered and enclosed at least $4 \mathrm{~h}$ before any measurement (Marsal et al., 2000).

Values of $\Psi_{\mathrm{PD}}$ were considered to be representative of the effective soil water potential on each day (Alarcón $e t$ al., 2003). Measured $\Psi_{\mathrm{L}, \mathrm{C}}$ were assumed to be equivalent to the stem xylem water potential to which the leaf is attached, whereas sunlit and shaded leaf water potential ( $\Psi_{\mathrm{L}, \mathrm{L}}$ and $\Psi_{\mathrm{L}, \mathrm{S}}$ respectively) correspond to an average of the xylem and the tissue water potential within the leaf itself (Clearwater et al., 2004). Thus, weighted canopy leaf water potential $\left(\Psi_{\mathrm{EC}}\right)$, including both sunlit and shaded leaves, was obtained for each hourly measurement set as (Cohen and Naor, 2002):

$$
\Psi_{\mathrm{EC}}=\alpha \Psi_{\mathrm{L}, \mathrm{L}}+(1-\alpha) \Psi_{\mathrm{L}, \mathrm{S}}
$$

where $\alpha$ is the sunlit leaf area fraction.

\section{Diurnal course of the sunlit leaf area fraction $(\alpha)$}

To determine $\alpha$, photosynthetic active radiation (PAR, 400-700 nm wavelength) interception measurements were carried out. PAR was chosen in order to have some comparative value with the visual estimation technique used by Moreshet et al. (1990) and Alarcón et al. (2003). This was done at three times during the season: 9 May, 1 June, and 10 July (DOY 131, 153, and 191, respectively), from 07:00 to 17:00 $\mathrm{h}$ (solar time) at $1 \mathrm{~h}$ intervals at two or three locations in the orchard, corresponding with the trees used for the hydraulic conductance determinations. Both, the incoming PAR and the amount transmitted beneath the canopy were measured using a linear quantum sensor (AccuPAR probe, Decagon Devices, Pullman, Washington, USA). The beam fraction of PAR received at seven positions on the orchard floor, from one alley-center to another ( $0.65 \mathrm{~m}$ of separation between measurements), was recorded. However, for any given hour, only the positions within the shadow cast by the hedgerow at that time were considered for calculations (Oyarzún, 2005). Thus, a was obtained as (Green et al., 2001, modified):

$$
\alpha=\left(\mathrm{IPAR}_{\mathrm{b}} / \mathrm{PAR}_{\mathrm{i}, \mathrm{h}}\right) /\left(\mathrm{L}_{\mathrm{t}} \cos (\mathrm{LIA})\right)
$$

where $\mathrm{IPAR}_{\mathrm{b}}$ is the intercepted beam PAR, PAR $\mathrm{i,h}$ is the incoming beam PAR, and LIA is the leaf inclination angle, determined using a LAI-2000 plant canopy analyzer ( $\mathrm{Li}$ Cor, Lincoln, Nebraska, USA) on 12 May (DOY 133) and assumed to be constant through the season.

\section{Hydraulic conductance}

The total plant hydraulic conductance to water flow, $\mathrm{K}_{\mathrm{T}}$ $\left(\mathrm{mmol} \mathrm{MPa}{ }^{-1} \mathrm{~s}^{-1}\right)$ was obtained using Ohm's law analogy (Alarcón et al., 2003; Tyree, 2003; Nicolás et al., 2005a; 2005b), as:

$$
\mathrm{K}_{\mathrm{T}}=\frac{\mathrm{E}}{\left(\Psi_{\mathrm{EC}}-\Psi_{\mathrm{PD}}\right)}
$$

It is assumed that $\Psi_{\mathrm{PD}}$ could be used as a proxy of bulk soil water potential under zero transpiration. Thus, the difference $\left(\Psi_{\mathrm{EC}}-\Psi_{\mathrm{PD}}\right)$ corresponds to the driving force for the flow of water from the soil to the leaves, and therefore, $\mathrm{K}_{\mathrm{T}}$ represents the plant total hydraulic conductance to that flow (Alarcón et al., 2003). Following the same analogy, the hydraulic conductance of the root/stem pathway, $K_{R}$, could be obtained as (Moreshet et al., 1990):

$$
K_{R}=\frac{E}{\left(\Psi_{X}-\Psi_{P D}\right)}
$$

It follows from Equations [5] and [6] that if $\mathrm{K}_{T}$ and $\mathrm{K}_{\mathrm{R}}$ remain fairly constant during the day, their values can be obtained from the slope of the linear regression between transpiration and either the $\Psi_{\mathrm{EC}}$ or $\Psi_{\mathrm{s}}$ (Tognetti et al., 2004).

Finally, it is possible to estimate the canopy hydraulic conductance (stem/leaf pathway), $\mathrm{K}_{\mathrm{C}}$, from (Moreshet $e t$ al., 1990; Alarcón et al., 2003):

$$
\mathrm{K}_{\mathrm{C}}=\left(\mathrm{K}_{\mathrm{T}}^{-1}-\mathrm{K}_{\mathrm{R}}^{-1}\right)^{-1}
$$

\section{Single leaf measurements}

Finally, for characterization purposes of the relative importance of different leaf areas (sunlit, shaded) in whole canopy transpiration, measurements of single leaf transpiration rates were carried out on both sunlit and 
shaded leaves on 12 June (DOY 164), at 2-h intervals from 08:00 to 16:00 h, using a CIRAS-2 portable photosynthesis system (PP Systems, Haverhill, Massachusetts, USA). Also, the corresponding $\Psi_{\mathrm{L}}$ for both sunlit and shaded leaves was determined using the PPC.

\section{RESULTS AND DISCUSSION}

The days of measurements exhibited rather similar meteorological conditions, relatively sunny with daily (hours of light) average air temperatures of around $28^{\circ} \mathrm{C}$, relative humidity of $40 \%$, slow to moderate wind speed of $1.8 \mathrm{~m} \mathrm{~s}^{-1}$, and reference evapotranspiration $\left(\mathrm{ET}_{0}\right)$ around $7 \mathrm{~mm} \mathrm{~d}^{-1}$.

Estimates of sunlit leaf area fraction were $c a .0 .35$, which are slightly lower than a assumed by Dragoni (2003, his Figure 49) based on apple trees of comparable dimensions and orchard conditions (planting distances,
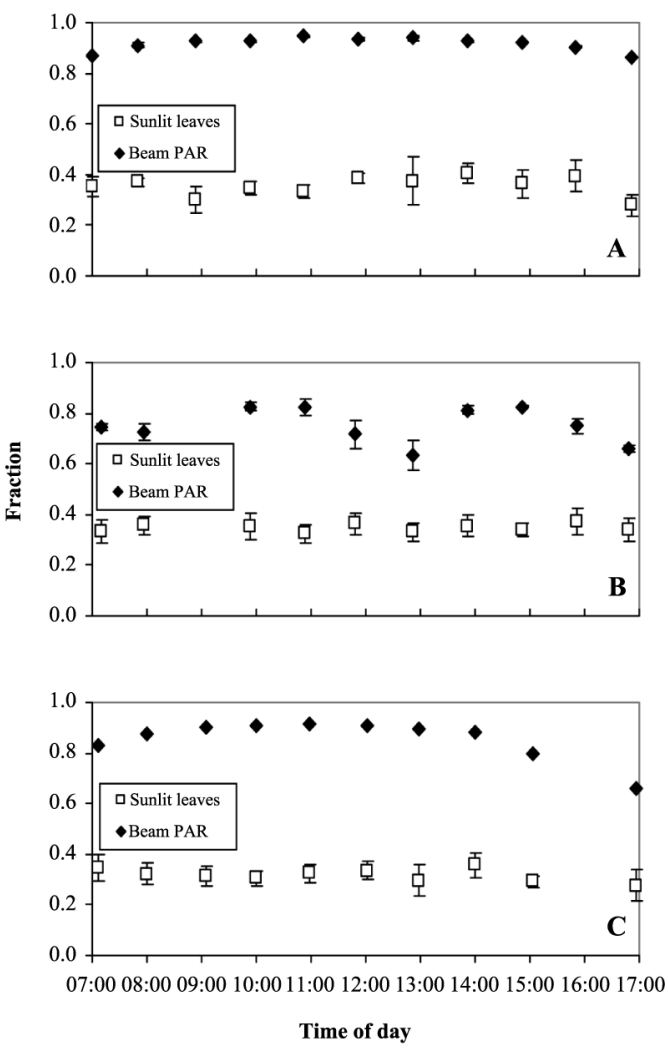

Figure 1. Diurnal course of the fraction of the sunlit leaf area (open square) and the beam component of the incoming photosynthetic active radiation (PAR, $\bullet$ ) on three different dates through the growing season: 9 May (panel $A)$, average leaf area per tree $\left(L_{t, a v g}\right)=$ $29.99 \mathrm{~m}^{2} ; 1$ June (panel B), $\mathrm{L}_{\mathrm{t}, \mathrm{avg}}=35.22 \mathrm{~m}^{2} ; 10$ July (panel $C$ ), $L_{t, \text { avg }}=38.20 \mathrm{~m}^{2}$. Each point is the mean of measurements performed under two (A) or three $(B, C)$ trees. Vertical bars are one standard error of the mean. Data points for momentaneous overcast conditions were neglected. time of the year, site latitude). In general, a did not show important fluctuations either within a given day or between the different days of measurements (Figure 1). Moreover, $\mathrm{K}_{\mathrm{T}}$ was rather insensitive whereas $\mathrm{Kc}$ was moderately sensitive to arbitrary changes in $\alpha$ (e.g., a $50 \%$ change in this variable resulted in a 3 to $7 \%$ change in $\mathrm{K}_{\mathrm{T}}$ and $c a$. $18 \%$ change in $K_{C}$; by definition $K_{R}$ is independent of $\alpha$ ). All these findings allowed us to empirically confirm the assumptions made by Moreshet et al. (1990) and Dragoni (2003).

Leaf water potential was lower for sunlit leaves than for shaded leaves that did not receive direct radiation from the sun but were still exposed to the environment, reaching daily minimum values of -2.2 to $-2.3 \mathrm{MPa}$ and -1.5 to $-1.6 \mathrm{MPa}$, respectively (Figure 2). Similar values, as well as daily patterns, have been described for other Prunus species (Smart and Barrs, 1973; Alarcón et al., 2003) as well as for apple trees (Deme, 1984; Brough et al., 1986).
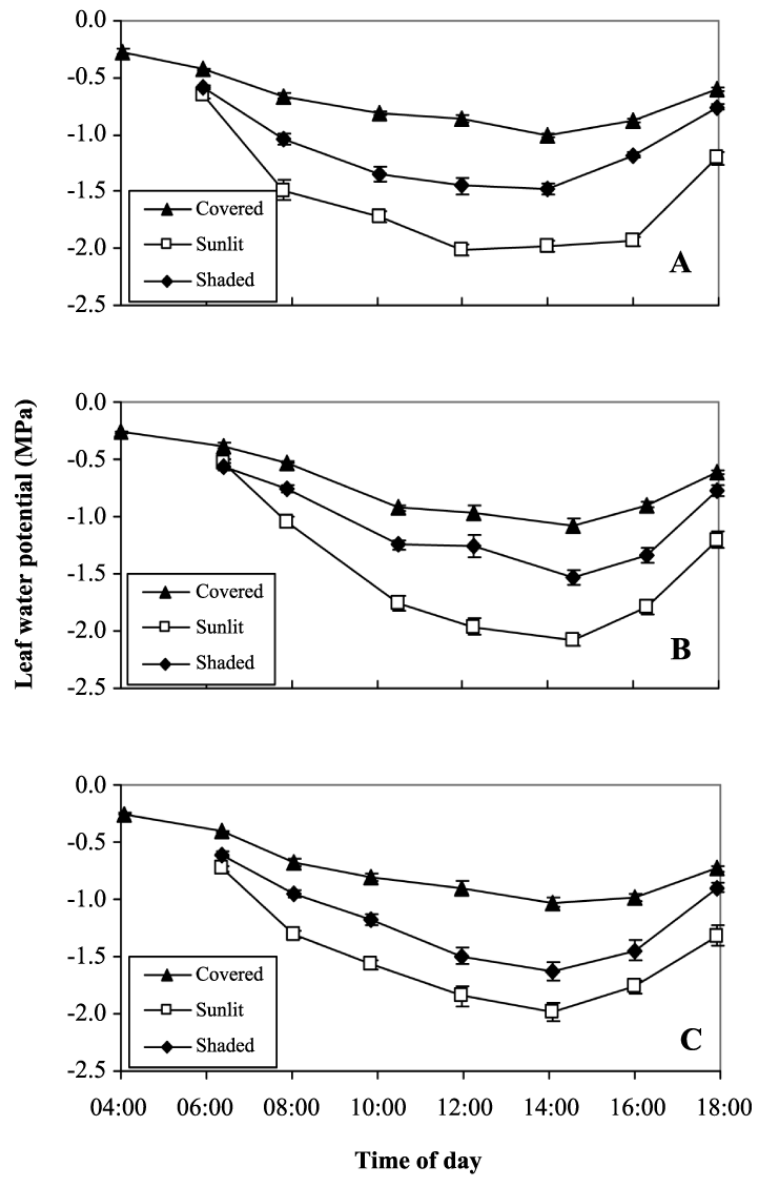

Figure 2. Diurnal course of leaf water potential for sunlit, shaded, and covered leaves on the selected days of whole canopy transpiration measurements: 4 June (panel A), 26 June (panel B), and 28 June (panel C). Each point is the mean of nine measurements (three per tree). Vertical bars correspond to one standard error of the mean. 

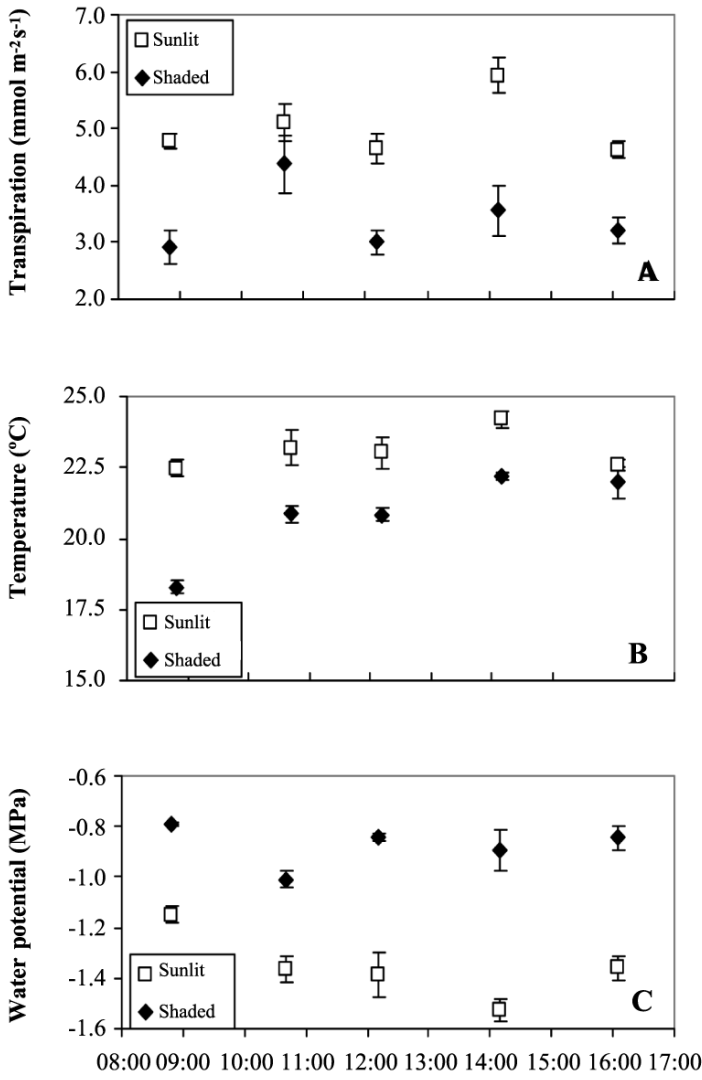

Time of day

Figure 3. Diurnal fluctuation of leaf transpiration rates (panel A), leaf temperature (panel B), and leaf water potential (panel C), on sunlit and shaded leaves on 12 June (DOY 164). Each point is the mean of six measurements (two trees, three leaves per tree). Vertical bars are one standard error of the mean.

Also, $\Psi_{\mathrm{L}}$ of both sunlit and shaded leaves was, at all times, lower that the corresponding value of the aluminumcovered non-transpiring leaves (Figure 2). The differences between shaded and covered $\Psi_{\mathrm{L}}$ is another indication that shaded leaves were transpiring, and therefore, that they should be considered in water relation assessment in a whole-tree basis analysis (Moreshet et al., 1990; Alarcón et al., 2003). Indeed, this situation was verified through the single leaf gas exchange measurements (Figure 3). Shaded leaves have, in general, lower temperatures (and, therefore, lower saturation pressure) and higher water potential (lower driving force) than sunlit leaves. Therefore, transpiration rates from shaded leaves are usually lower than those of sunlit leaves, a phenomenon confirmed for sweet cherry by our study. However, the contribution of shaded leaves to overall tree transpiration could be significant because they accounted for $c a .65 \%$ of total leaf area. The importance of shaded leaves in
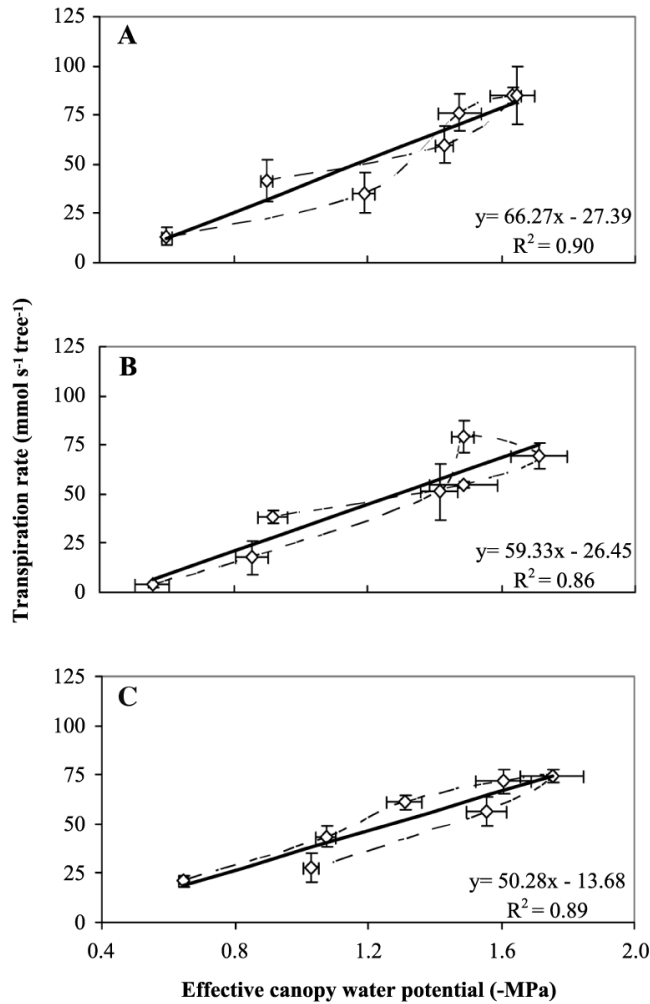

Figure 4. Relationship between whole trees weighted leaf water potential $\left(\Psi_{\mathrm{EC}}\right)$ and transpiration $\left(\mathrm{E}, \mathrm{mmol} \mathrm{s} \mathbf{s}^{-1}\right)$ on the different days of measurements: 4 June (panel A), 26 June (panel B), and 28 June (panel C). Each point is the mean of data obtained in three different trees. Horizontal and vertical bars are one standard error of the mean. Dashed lines represent the daily path (course of time).

terms of their contribution to the total plant transpiration has been described and discussed as well for other fruit trees such as citrus, kiwi, and apricot (Moreshet et al., 1990; Xiloyannis et al., 2000).

The instantaneous rates of whole tree transpiration, as determined using the whole canopy chambers, were plotted against the simultaneous measurements of effective canopy and xylem water potential (Figures 4 and 5 ), in order to obtain the total plant hydraulic conductance and the root-stem component. The resulting regression equations yielded values that ranged between 50-66 and 85-131 (mmol s${ }^{-1} \mathrm{MPa}^{-1}$ ) for $\mathrm{K}_{\mathrm{T}}$ and $\mathrm{K}_{\mathrm{R}}$ respectively.

A subtle "figure eight" pattern was observed in the daily trajectory of E vs. $\Psi_{\mathrm{EC}}$ (Figure 4). This kind of pattern has been described by Larsen et al. (1989) to be characteristic for well-watered stone fruits trees in areas where afternoon "leaf-to-air vapor density difference" becomes high, which likely occurred on the measurements days (data not shown). 
Hysteresis in this relationship, i.e., $\mathrm{y}_{\mathrm{L}}$ lagging behind transpiration, has been interpreted in terms of the existence of water storage within the tissues of the stems of trees (Brough et al., 1986; Wullschleger et al., 1998). Indeed, similar results were presented by Waring and Running (1978) for three selected days during summer, on a 2 month period, for Douglas fir Pseudotsuga menziesii (Mirb.) Franco trees, as well as by Brough et al. (1986) for apple trees on 2 d over a 1 month period. Waring and Running (1978) explained their results in terms of reductions on the sapwood water content through the time period analyzed, while no explanation was given by Brough et al. (1986). Nevertheless, in the case of the cherry trees here studied, this behavior was noticeable only on the first two dates and not observable on the third measurement day. In addition, the plotted results yielded significant $\left(\mathrm{R}^{2} \sim 0.9\right.$; $\mathrm{P}<0.01)$ linear relationships between $\mathrm{E}$ and $\Psi_{\mathrm{EC}}$, and the slopes of trend lines, estimator of $\mathrm{K}_{\mathrm{T}}$, did not vary much between measurement dates. These are important evidences that allow us to state that the hysteresis detected is of marginal relevance. Indeed, the occurrence of a
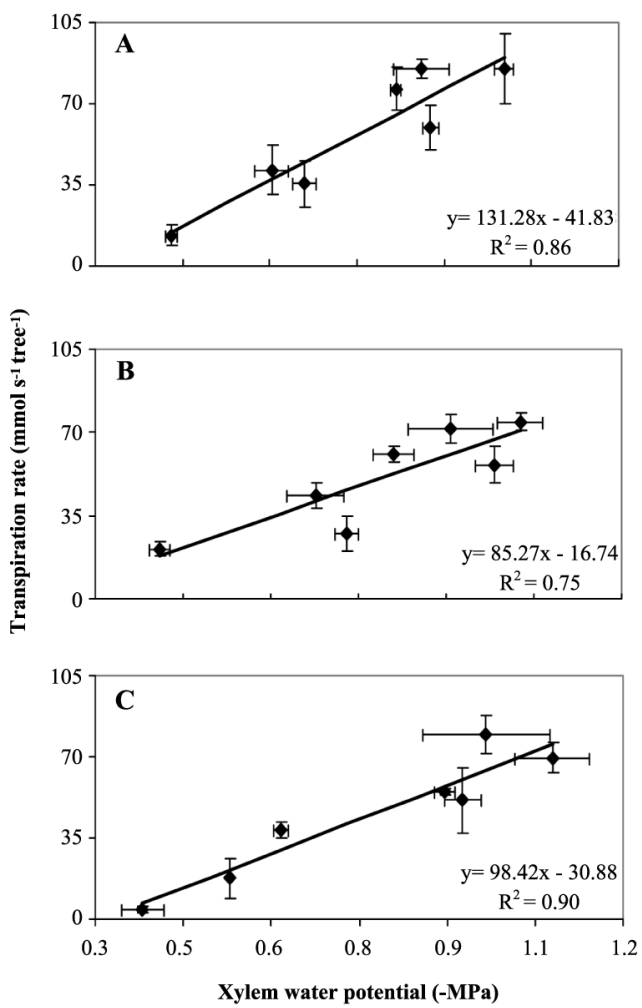

Figure 5. Relationship between xylem water potential, as determined from aluminum-covered leaves $\left(\Psi_{L, C}\right)$ and transpiration on the different days of measurements: 4 June (panel A), 26 June (panel B), and 28 June (panel C). Each point is the mean of registers obtained in three different trees. Horizontal and vertical bars are one standard error of the mean. The seven points of each figure represent the measurements at $2 \mathrm{~h}$ intervals. statistically significant linear relationship between $\mathrm{E}$ and $\Psi$ has been considered elsewhere as an indication of a negligible capacitance effect in several fruit trees (Elfving et al., 1972; Cohen et al., 1983; Naor and Wample, 1994; Steinberg et al., 1990; Alarcón et al., 2003; Tognetti et al., 2004; Cohen et al., 2007). Also, for each day separately, E variations resulted in proportional changes in $\Psi_{\mathrm{EC}}$, showing that conductances remained constant on a diurnal basis. Similar results have been also found or described for other fruit trees such as oranges (Cohen et al., 1997), apples (Peretz et al., 1984), pecan (Steinberg et al., 1990), grapevines (Naor and Wample, 1994), and apricot (Nicolás et al., 2005a; 2005b), which reinforces the idea of low water capacitance for the cherry trees. Therefore, the use of the Ohm's analogy seems valid, and the results support the use of models that approach the estimation of water uptake rates assuming steady state conditions.

There was also a slight trend of decreasing conductances, in both $\mathrm{K}_{\mathrm{T}}$ and $\mathrm{K}_{\mathrm{R}}$, and therefore also $\mathrm{K}_{\mathrm{C}}$, comparing the different dates of measurements. Changes in hydraulic conductances in plants may occur as a consequence of both exogenous factors, such as temperature or water stress periods, and endogenous factors, like changes in sap flow composition (Peretz et al., 1984; Sperry et al., 2003; Tognetti et al., 2004). For fruit trees, a variable situation appears. Plant conductance adjustment or changes though the season have been mentioned in species like apple (Peretz et al., 1984), orange (Elfving et al., 1972), olive (Olea europaea L.) (Tognetti et al., 2004), and peach (Prunus persica L.) (Marsal et al., 2000), meanwhile for kiwi, Clearwater et al. (2004) did not find consistent seasonal or daily changes in conductances. Differences among sample dates in the current study were small. Therefore, it seems reasonable to consider an average value of conductance as representative for a preliminary assumption in further studies and interpretations for sweet cherry. This has also been mentioned or assumed as valid for other fruit trees such as apple (Deme, 1984) and kiwi (Clearwater et al., 2004) as well as in general for forest trees growing under adequate soil water conditions (Wullschleger et al., 1998).

An average of $\mathrm{K}_{\mathrm{T}}=59.3 \mathrm{mmol} \mathrm{s}^{-1} \mathrm{MPa}^{-1}$ and $\mathrm{K}_{\mathrm{R}}=101.5$ mmol s${ }^{-1} \mathrm{MPa}^{-1}$ was obtained when all the individual set of measurements were plotted together (data not shown). Using Equation [7], the average hydraulic conductance of the steam-leaf pathway, $\mathrm{K}_{\mathrm{C}}$, was estimated to be 142.6 mmol s${ }^{-1} \mathrm{MPa}^{-1}$. Both $\mathrm{K}_{\mathrm{R}}$ and $\mathrm{K}_{\mathrm{C}}$ were, on average, of the same order of magnitude, with the former being lower than the latter and therefore the limiting factor in terms of liquid water transport through the cherry trees. This is in agreement with results found for other fruit trees such as apple, citrus, peach, and kiwi (Deme, 1984; Moreshet et al., 1990; Alarcón et al., 2003; Clearwater et al., 2004). 


\section{CONCLUSIONS}

The total plant hydraulic conductance of sweet cherry trees was $c a$. $60 \mathrm{mmol} \mathrm{s}^{-1} \mathrm{MPa}^{-1}$. The analysis of its components showed that it was higher on the stem-leaf pathway and lower in the root-stem component, which is in agreement with reports for other fruit trees such as apple. The diurnal path of transpiration vs. leaf water potential values slightly describes an eight-pattern, considered as an indicator of hysteresis behavior, on two measurement days, while it was not noticeable on a third day. Then, and considering that the plotted results yielded significant linear relationships with similar slopes, it is possible to conclude that the studied cherry trees do no present an important water storage component that may affect the hydraulic conductance determinations performed.

\section{ACKNOWLEDGEMENTS}

This research was partially funded by the project FONDEF D021-1146. The technical assistance of A. Milla in the field data acquisition is greatly appreciated, as well as the assistance of D. Strausz and D. Orphardt during the whole canopy chambers operation. The paper benefited from the comments of an anonymous reviewer and the editor.

\section{RESUMEN}

Análisis de los componentes de conductancia hidráulica en árboles maduros de cerezo dulce en condiciones de campo. Como un paso necesario para la comprensión de la extracción de agua desde el suelo y las relaciones sueloagua-planta, los componentes de la conductancia hidráulica (K) en árboles adultos de cerezo (Prunus avium L.) fue evaluada in situ con un método basado en una analogía de la Ley de Ohm. En Junio de 2004, K fue determinada para árboles 'Bing'/“Gisela ${ }^{\circledR} 5$ ' de 10 años de edad, a partir de mediciones simultáneas de intercambio gaseoso del follaje en forma integrada y potenciales hídricos $(\Psi)$ de hojas individuales (soleadas y sombreadas) y del xilema. Los potenciales hídricos de las hojas soleadas fueron menores que los de las hojas sombreadas, alcanzando valores mínimos de ca. -2.3 MPa alrededor de 14:00 h (hora solar). La conductancia hidráulica promedio total fue de $60 \pm 6 \mathrm{mmol} \mathrm{s}^{-1} \mathrm{MPa}^{-1}$, presentando una leve disminución en la medida que la temporada avanzó. El análisis de los componentes de la conductancia hidráulica mostró que ésta fue mayor en la sección xilema-hoja $(150 \pm 50 \mathrm{mmol}$ $\left.\mathrm{s}^{-1} \mathrm{MPa}^{-1}\right)$ y menor en el tramo raíz-xilema $(100 \pm 20 \mathrm{mmol}$ $\left.\mathrm{s}^{-1} \mathrm{MPa}^{-1}\right)$, lo que es concordante con estudios previos en otros árboles frutales. Se observó un débil patrón de histéresis en la relación diaria entre la transpiración total del árbol (ponderando las hojas soleadas y sombreadas) vs. $\Psi$, lo que sugiere que el almacenamiento al interior de los árboles de cerezo no es un componente importante en su balance hídrico.

Palabras clave: relaciones hídricas de plantas, Prunus avium, transpiración, potencial hídrico, intercambio gaseoso de canopia.

\section{LITERATURE CITED}

Alarcón, J.J., R. Domingo, S.R. Green, E. Nicolás, and A. Torrecillas. 2003. Estimation of hydraulic conductance within field-grown apricot using sap flow measurements. Plant Soil 251:125-135.

Ameglio, T., P. Archer, M. Cohen, C. Valancogne, F.A. Daudet, S. Dayau, and P. Cruiziat. 1999. Significance and limits in the use of predawn water potential for tree irrigation. Plant Soil 207:155-167.

Atkinson, C., and M. Else. 2001. Understanding how rootstock dwarf fruit trees. Compact Fruit Tree 34:46-49.

Basile, B., J. Marsal, L.I. Solari, M.T. Tyree, D.R. Bryla, and T.M. De Jong. 2003. Hydraulic conductance of peach trees grafted on rootstocks with differing size-controlling potentials. J. Hort. Sci. Biotech. 78:768-774.

Brough, D.W., H.G. Jones, and J. Grace. 1986. Diurnal changes in water content of the stems of apple trees, as influenced by irrigation. Plant Cell Environ. 9:1-7.

Clearwater, M.J., R.G. Lowe, B.J. Hofstee, C. Barclay, A.J. Mandemaker, and P. Blattman. 2004. Hydraulic conductance and rootstock effects in grafted vines of kiwifruit. J. Exp. Bot. 55:1371-1382.

Cohen, Y., M. Fuchs, and S. Cohen. 1983. Resistance to water uptake in a mature citrus tree. J. Exp. Bot. 34:451-460.

Cohen, S., S. Moreshet, L. Le Guillou, J.C. Simon, and M. Cohen. 1997. Response of citrus trees to modified radiation regime in semi-arid conditions. J. Exp. Bot. 48:35-44.

Cohen, S., and A. Naor. 2002. The effect of three rootstocks on water use, canopy conductance and hydraulic parameters of apple trees and predicting canopy from hydraulic conductance. Plant Cell Environ. 25:17-28.

Cohen, S., A. Naor, J. Bennink, A. Grava, and M. Tyree. 2007. Hydraulic resistance components of mature apple trees on rootstocks of different vigours. J. Exp. Bot. 58:4213-4224.

Deme, I. 1984. Modeling apple tree response to soil moisture. 120 p. M.Sc. Thesis. Washington State University, Pullman, Washington, USA. 
Dragoni, D. 2003. Measuring and modeling water fluxes in apple orchards and vineyards in the humid climate of the North Eastern US. 131 p. Ph.D. diss. Cornell University, Ithaca, New York, USA.

Dragoni, D., A.N. Lakso, and R.M. Piccioni. 2005. Transpiration of apple trees in a humid climate using heat pulse sap flow gauges calibrated with wholecanopy gas exchange chambers. Agric. For. Meteorol. 130:85-94.

Elfving, D.C., M. Kauffmann, and A.E. Hall. 1972. Interpreting leaf water potential measurements with a model of the soil-plant-atmosphere continuum. Physiol. Plant. 27:161-168.

Green, S.R., H.D. Greer, J.N. Wunsche, and H. Caspari. 2001. Measurements of light interception and utilization in an apple orchard. Acta Hort. (ISHS) 557:369-376.

Hubbard, R.M., M.G. Ryan, V. Stiller, and J.S. Sperry. 2001. Stomatal conductance and photosynthesis vary linearly with plant hydraulic conductance in ponderosa pine. Plant Cell Environ. 24:113-121.

Larsen, F.E., S.S. Higgins, and A. Al Wir. 1989. Diurnal water relations of apple, apricot, grape, olive and peach in an arid environment (Jordan). Sci. Hortic. (Canterbury, Engl.) 39:211-222.

Liu, W.T., W. Wenkert, L.H. Allen, and E.R. Lemon. 1978. Soil-plant water relations in a New York vineyard: resistances to water movement. J. Amer. Soc. Hort. Sci. 103:226-230.

Lovisolo, C., W. Hartung, and A. Schubert. 2002. Wholeplant hydraulic conductance and root-to-shoot flow of abscisic acid are independently affected by water stress in grapevines. Funct. Plant Biol. 29:1349-1356.

Marsal, J., M. Mata, M. Nelly, and J. Girona. 2000. Does peach tree hydraulic resistance play any role in maximum daily trunk shrinkage? Acta Hort. (ISHS) 537:337-344.

Meinzer, F.C., M.J. Clearwater, and G. Goldstain. 2001. Water transport in trees: current perspectives, new insights and some controversies. Environ. Exp. Bot. 45:239-262.

Moreshet, S., Y. Cohen, G.C. Green, and M. Fuchs. 1990. The partitioning of hydraulic conductances within mature orange trees. J. Exp. Bot. 41:833-839.

Naor, A., and R.L. Wample. 1994. Gas exchange and water relations of field grown concord (Vitis labruscana Bailey) grapevines. Am. J. Enol. Viticult. 45:333-337.

Nicolás, E., A. Torrecillas, J. Dell'Amico, and J.J. Alarcón. 2005a. Sap flow, gas exchange and hydraulic conductance of young apricot trees growing under a shading net and different water supplies. J. Plant Physiol. 162:439-447.
Nicolás, E., A. Torrecillas, J. Dell'Amico, and J.J. Alarcón. 2005b. The effect of short-term flooding on the sap flow, gas exchange and hydraulic conductivity of young apricot trees. Trees 19:51-57.

Olmstead, M.A., N.S.Lang, F.W. Ewers, and S.A. Owens. 2006. Xylem vessel anatomy of sweet cherries grafted onto dwarfing and nondwarfing rootstocks. J. Amer. Soc. Hort. Sci. 131:577-585.

Oyarzún, R. 2005. Measurement and modeling of plant hydraulic conductance and solar radiation transfer processes in fruit tree orchards, with special reference to sweet cherry. 170 p. Ph.D. diss. Washington State University, Pullman, Washington, USA.

Peretz, J., R.G. Evans, and E.L. Proebsting. 1984. Leaf water potential for management of high frequency irrigation of apples. Paper $\mathrm{N}^{\circ} 81-2557$. Winter Meeting of American Society of Agricultural Engineers, Chicago, Illinois. Dec. 15-18. American Society of Agricultural Engineers (ASAE), St. Joseph, Michigan, USA.

Schultz, H.R. 2003. Differences in hydraulic architecture account for near-isohydric and anisohydric behaviour of two field-grown Vitis vinifera L. cultivars during drought. Plant Cell Environ. 26:1393-1405.

Smart, R.E., and H.D. Barrs. 1973. The effect of environmental and irrigation interval on leaf water potential of four horticultural species. Agric. Meteorol. 12:337-346.

Sperry, J.S., V. Stiller, and U.G. Hacke. 2003. Xylem hydraulics and the soil-plant-atmosphere continuum: opportunities and unresolved issues. Agron. J. 95:1362-1370.

Steinberg, S.L., M.J. McFarland, and J.W. Worthington. 1990. Comparison of trunk and branch sap flow with canopy transpiration in pecan. J. Exp. Bot. 41:653659.

Tognetti, R., R. d'Andria, G. Morelli, D. Calandrelli, and F. Fragnito. 2004. Irrigation effects on daily seasonal variations of trunk sap flow and leaf water relations in olive trees. Plant Soil 263:249-264.

Tyree, M.T. 2003. Hydraulic limits on tree performance: Transpiration, carbon gain and growth of trees. Trees 17:95-100.

Waring, R.H., and S.W. Running. 1978. Sapwood water storage: its contribution to transpiration and effect upon water conductance through the stems of oldgrowth Douglas-fir. Plant Cell Environ. 1:131-140.

Whiting, M.D. 2001. Whole canopy source-sink relations and fruit quality in 'Bing' sweet cherry trees on a dwarfing, precocious rootstock. 150 p. Ph.D. diss. Washington State University, Pullman, Washington, USA. 
Wullschleger, S.D., F.Z. Meinzer, and R.A.Vertessy. 1998. A review of whole plant water use studies in trees. Tree Physiol. 18:499-512.
Xiloyannis, C., V. Nuzzo, B. Dichio, G. Celano, and G. Montanaro. 2000. Characterization of training systems in relation to water use efficiency in apricot and kiwifruit plants. Acta Hort. (ISHS) 537:207-213. 